\title{
MOBILE ROBOT DENGAN PENGONTROLAN PERINTAH SUARA BERBASIS ANDROID
}

\author{
Eko Sulistyo $^{1}$ \\ 1 Jurusan Teknik Elektro dan Informatika, Politeknik Manufaktur Negeri Bangka Belitung \\ Kawasan Industri Air Kantung Sungailiat - 33211 \\ Telp. (0717) 93586, Fax. (0717) 93585, sulistyo.eko@gmail.com
}

\begin{abstract}
Control of mobile robot manually using remote control connected with cable has constraints that limited space of robot movement. For that developed mobile robot control system using bluetooth communication. The purpose of this research is to create a mobile robot control system through wireless communication using voice command instruction via application on Android using microcontroller type Arduino Mega2560. The methodology in this research is the voice instruction will be recorded by the application on Android, then matched with the database and then converted into characters in the form of strings and sent via bluetooth transmitter on Android to bluetooth receiver on mobile robot to be executed by program made on microcontroller robot. The results obtained include mobile robot can move to follow voice command instruction that is given include command forward, backward, turn left and right only for one movement while in test result got error of movement equal to $1.55 \%$ with response time 4-7 second because the process of recording and translation of voice instructions on Android and also influenced by noise or other sounds that are not desired.
\end{abstract}

Keywords: android, bluetooth, mobile robot, voice command

\begin{abstract}
Abstrak
Pengontrolan mobile robot secara manual menggunakan remote control yang terhubung dengan kabel memiliki kendala yaitu ruang gerak robot yang terbatas. Untuk itu dikembangkan sistem pengontrolan mobile robot menggunakan komunikasi nirkabel jenis bluetooth. Tujuan penelitian ini adalah untuk membuat sebuah sistem pengontrolan mobile robot melalui komunikasi jarak jauh menggunakan instruksi perintah suara melalui aplikasi pada Android menggunakan mikrokontroler jenis Arduino Mega2560. Metodologi dalam penelitian ini yaitu instruksi suara direkam oleh aplikasi pada Android, selanjutnya dicocokkan dengan database lalu diubah menjadi karakter string dan dikirimkan melalui bluetooth transmitter pada Android ke bluetooth receiver pada mobile robot untuk kemudian dieksekusi oleh program yang dibuat pada mikrokontroler robot. Hasil yang didapatkan antara lain mobile robot dapat bergerak mengikuti instruksi voice command yang diberikan meliputi perintah maju, mundur, putar kiri dan putar kanan hanya untuk satu pergerakan sedangkan pada hasil pengujian didapatkan error pergerakan rata-rata sebesar 1.55\% dengan waktu respon 4-7 detik dikarenakan adanya proses perekaman dan penerjemahan instruksi suara pada Android dan juga dipengaruhi oleh noise atau suara lain yang tidak diinginkan.
\end{abstract}

Kata kunci: android, bluetooth, mobile robot, perintah suara

\section{PENDAHULUAN}

Mobile Robot adalah salah satu jenis konstruksi robot yang ciri khasnya adalah mempunyai aktuator berupa roda untuk menggerakkan keseluruhan badan robot, sehingga robot tersebut dapat melakukan perpindahan posisi dari satu titik ke titik yang lain. Salah satu jenis mobile robot yaitu robot beroda atau wheeled mobile robot. Menurut sistem penggeraknya robot beroda diklasifikasikan berdasarkan jumlah roda yang digunakan. Salah satunya yaitu robot beroda dengan sistem gerak differential drive yang terdiri dari dua buah roda yang berpasangan pada kiri dan kanan robot. Sistem ini memunginkan robot berputar ditempat dengan cara memutar motor dengan arah berlawanan [1].

Pengontrolan mobile robot pada awalnya masih bersifat manual menggunakan remote control yang terhubung dengan kabel. Hal ini mempengaruhi ruang gerak robot menjadi terbatas. Perkembangan ilmu dan teknologi saat ini dapat diterapkan dalam mengembangkan sistem pengontrolan pada mobile robot, salah satunya adalah penggunaan komunikasi nirkabel jenis bluetooth. 
Selain itu, penggunaan remote control secara manual sangat rentan terhadap risiko kerusakan pada rangkaian kontrol didalamnya. Oleh karena itu, digunakanlah smartphone berbasis OS Android dalam mengontrol pergerakan pada mobile robot. Penggunaan smartphone dalam mengontrol mobile robot dapat memanfaatkan fitur-fitur yang ada pada smartphone salah satunya fitur pengolahan suara (speech recognition). Speech recognition atau pengenalan ucapan adalah suatu pengembangan teknik dan sistem yang memungkinkan komputer untuk menerima masukan berupa kata yang diucapkan. Teknologi ini memungkinkan suatu perangkat untuk mengenali dan memahami kata-kata yang diucapkan dengan cara digitalisasi kata dan mencocokkan sinyal digital tersebut dengan suatu pola tertentu yang tersimpan dalam suatu perangkat. Hasil dari identifikasi kata yang diucapkan dapat ditampilkan dalam bentuk tulisan atau dapat dibaca oleh perangkat teknologi sebagai sebuah komando untuk melakukan suatu pekerjaan (Ardi, 2014).Alat pengenal ucapan yang sering disebut dengan speech recognizer, membutuhkan sampel kata. Sampel kata akan didigitalisasi, disimpan dalam komputer, dan kemudian digunakan sebagai basis data dalam mencocokkan kata yang diucapkan selanjutnya.

Berdasarkan latar belakang tersebut, dibuatlah sebuah sistem pengontrolan mobile robot dengan menggunakan aplikasi perintah suara (voice command) pada smartphone Android yang dilengkapi dengan menggunakan sensor jarak rotary encoder dan sensor kompas untuk dapat menentukan titik berupa jarak dan sudut yang akan ditempuh mobile robot serta sensor Ultrasonik untuk mendeteksi rintangan pada saat robot melakukan pergerakan. Adapun tujuan dari penelitian ini yaitu untuk merancang dan membuat sebuah sistem pengontrolan mobile robot dengan menggunakan instruksi berupa perintah suara (voice command) berbasis Android.

\section{METODE PENELITIAN}

Pengontrolan mobile robot menggunakan instruksi via voice command melalui aplikasi Android menggunakan metodologi berikut.

- Pembuatan konstruksi mobile robot, konstruksi mobile robot yang dibuat menggunakan sistem gerak differential drive yang terdiri dari dua buah roda yang berpasangan pada bagian kiri dan kanan robot. Berdasarkan konstruksi yang dibuat pergerakan mobile robot yang dirancang meliputi gerakan maju, mundur serta berputar (kiri dan kanan).

- Pembuatan kontrol mobile robot, proses ini dimulai dari perekaman instruksi suara oleh aplikasi Android dengan menggunakan fitur speech recognizer. Selanjutnya data instruksi suara dicocokkan dengan database yang dimiliki pada Android. Hasil pencocokan data kemudian dikirimkan melalui bluetooth transmitter pada Android. Hasil pengiriman data kemudian diterima oleh bluetooth receiver pada mobile robot dalam bentuk data serial. Data tersebut kemudian diolah mikrokontroller untuk proses pergerakan pada mobile robot.

- Pengujian mobile robot, pengujian yang dilakukan meliputi pengujian kontrol mobile robot dan pengujian gerakan mobile robot berdasarkan instruksi voice command.

\section{HASIL DAN PEMBAHASAN}

\subsection{Pembuatan Konstruksi Mobile Robot}

Mobile robot dirancang dan dibuat dengan bahan material yang digunakan adalah acrylic dengan ketebalan $3 \mathrm{~mm}$. Berikut adalah gambar konstruksi mekanik mobile robot yang telah jadi ditunjukkan pada Gambar 1.

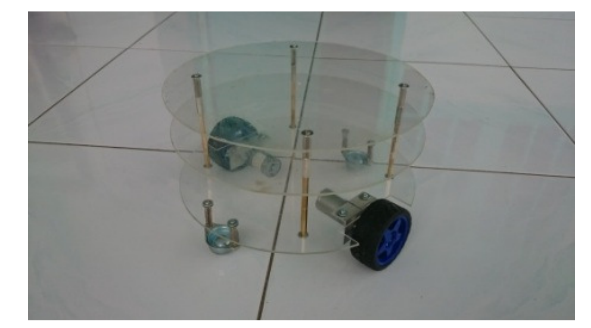

Gambar 1. Konstruksi Mekanik Mobile Robot 
Perakitan konstruksi mobile robot menggunakan komponen spacer, baut dan mur untuk menyatukan seluruh bagian dari konstruksi mobile robot.

\subsection{Pembuatan Hardware dan Software Mobile Robot}

Proses pembuatan hardware meliputi pembuatan rangkaian kontrol yang digunakan untuk mengontrol mobile robot yaitu pembuatan rangkaian catu daya, rangkaian LCD 2x16 serta perakitan sensor dan modul lainnya pada konstruksi yang telah dibuat. Diagram blok hardware elektronik mobile robot ditunjukkan pada gambar 2 .

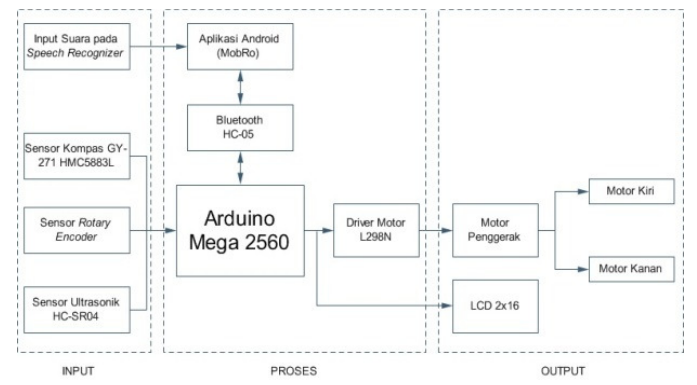

Gambar 2. Diagram hardware elektronik Blok Mobile Robot

Instruksi perintah suara diberikan dengan memanfaatkan fitur speech recognizer pada aplikasi MoBro yang dibuat di Android. Instruksi suara akan direkam pada Android kemudian diubah menjadi karakter string dan dikirimkan ke Arduino Mega 2560 untuk kemudian dieksekusi oleh aktuator mobile robot berupa pergerakan pada motor kiri dan kanan menggunakan modul driver L298N dengan feedback berupa sensor rotary encoder, kompas GY-271 dan ultrasonik HC-SR04.

Pembuatan software pada mobile robot meliputi pembuatan aplikasi pada Android serta pemrograman Arduino Mega2560. Pembuatan aplikasi Android menggunakan software app inventor secara online menggunakan PC/Komputer. Pembuatan aplikasi ini dibagi menjadi 2 komponen utama yaitu designer dan block editor. Berikut adalah gambar aplikasi MoBro yang telah dibuat dapat dilihat pada Gambar 3.

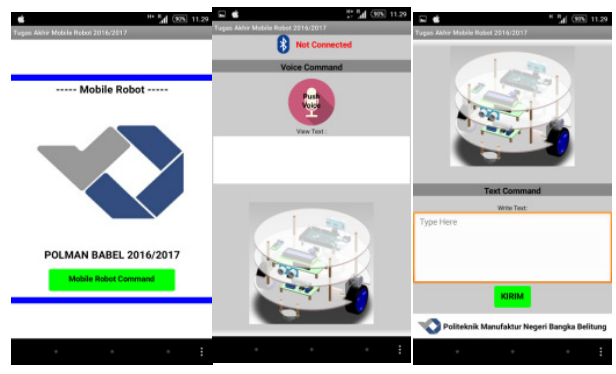

Gambar 3. Aplikasi MoBro pada Android

Pembuatan program dilakukan menggunakan software Arduino 1.6.8. Pemrograman mobile robot yang dilakukan meliputi pemrograman bluetooth HC-05, sensor kompas GY-271 HMC5883L, LCD $2 \times 16$, sensor rotary encoder, driver motor L298N serta pemrograman mobile robot secara keseluruhan. Adapun Mobile Robot yang telah dibuat dapat dilihat pada gambar 4 berikut.

\subsection{Pengujian Mobile Robot}

Pengujian mobile robot yang dilakukan meliputi pengujian koneksi bluetooth, pengujian instruksi aplikasi Android dan pengujian gerakan robot. Pada pengujian koneksi bluetooth didapatkan hasil pengujian bluetooth yang digunakan dapat menerima data yang dikirim oleh aplikasi pada Android hingga jarak 12 meter dengan baik pada ruangan tanpa penghalang. Sedangkan pengujian terhadap aplikasi Android (MoBro) didapatkan hasil aplikasi MoBro yang dibuat dapat menerima data berupa instruksi 
suara, namun pada beberapa uji coba yang dilakukan, apabila kata yang diucapkan berupa satuan maka kata tersebut akan dirubah menjadi simbol, misalnya centimeter menjadi cm dan lain sebagainya. Untuk mencegah terjadinya error maka hal ini diolah pada pemrograman Arduino Mega2560 agar setiap kata maupun karakter satuan yang dikirim oleh aplikasi dapat dieksekusi oleh mobile robot. Adapun hasil pengujian ditunjukkan pada Tabel 1.

Tabel 1. Hasil Pengujian Aplikasi MoBro

\begin{tabular}{cc}
\hline Instruksi & Data Voice Command \\
\hline maju & maju \\
mundur & mundur \\
putar kiri & putar kiri \\
putar kanan & putar kanan \\
meter & $\mathrm{m}$ \\
centimeter & $\mathrm{cm}$ \\
1 meter & 1 meter \\
1 centimeter & $1 \mathrm{~cm}$ \\
derajat & derajat \\
180 derajat & $180^{\circ}$ \\
\hline
\end{tabular}

Pengujian pergerakan robot dilakukan dengan memberikan instruksi yang diberikan pada robot, Pergerakan robot ini mencakup berbagai arah gerakan. Gambar dari arah pergerakan yang dapat dilakukan mobile robot ditunjukkan pada Gambar 4 berikut.

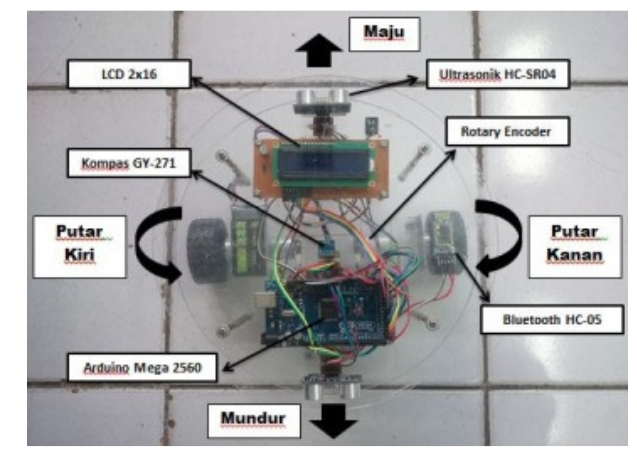

Gambar 4. Pergerakan yang Dilakukan Mobile Robot

Perhitungan persentase error pada pergerakan mobile robot dilakukan menggunakan persamaan berikut.

$$
\% \text { error }=\left|\frac{\text { nilai teori }- \text { nilai pengukuran }}{\text { nilai teori }}\right| \times 100 \%
$$

Hasil pengujian pergerakan maju ditunjukkan pada Tabel 2 berikut.

Tabel 2 Hasil Pengujian Gerakan Maju

\begin{tabular}{cccc}
\hline \multicolumn{4}{c}{ Data Percobaan Maju } \\
\hline Jarak $(\mathrm{cm})$ & Pengukuran $(\mathrm{cm})$ & Error $(\%)$ & Waktu Respon \\
1 & 1,1 & $10 \%$ & 4 detik \\
5 & 5 & $0 \%$ & 5 detik \\
10 & 10,2 & $2 \%$ & 5 detik \\
20 & 20,3 & $1,5 \%$ & 4 detik \\
50 & 50,5 & $1 \%$ & 6 detik \\
75 & 75,4 & $0,53 \%$ & 5 detik \\
100 & 100,5 & $0,5 \%$ & 6 detik \\
200 & 201,2 & $0,6 \%$ & 5 detik \\
300 & 300,2 & $0,07 \%$ & 4 detik
\end{tabular}




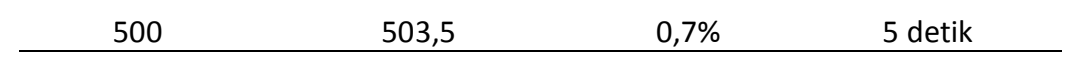

Hasil pengujian pergerakan putar kanan ditunjukkan pada Tabel 3 berikut.

Tabel 3 Hasil Pengujian Gerakan Putar Kanan

\begin{tabular}{cccc}
\hline \multicolumn{4}{c}{ Data Percobaan Putar Kanan } \\
\hline Sudut (derajat) & Pengukuran (derajat) & Error (\%) & Waktu Respon \\
10 & 9 & $10 \%$ & 5 detik \\
30 & 30 & $0 \%$ & 6 detik \\
60 & 59 & $1,67 \%$ & 5 detik \\
90 & 88 & $2,22 \%$ & 5 detik \\
120 & 118 & $1,67 \%$ & 5 detik \\
150 & 146 & $2,67 \%$ & 4 detik \\
180 & 176 & $2,22 \%$ & 6 detik \\
210 & 208 & $0,95 \%$ & 6 detik \\
240 & 238 & $0,83 \%$ & 6 detik \\
270 & 270 & $0 \%$ & 6 detik \\
300 & 299 & $0,33 \%$ & 5 detik \\
330 & 330 & $0 \%$ & 5 detik \\
360 & 360 & $0 \%$ & 6 detik \\
\hline
\end{tabular}

Berdasarkan pengujian yang dilakukan didapatkan bahwa mobile robot dapat bergerak sesuai dengan instruksi perintah suara yang diberikan dengan baik antara lain perintah maju, mundur, putar kiri dan putar kanan hanya untuk satu pergerakan saja. Pada hasil pengujian yang dilakukan diperoleh waktu respon yang diperlukan dari selesai pemberian instruksi perintah suara pada Android hingga mobile robot bergerak adalah 4-7 detik. Hal ini dikarenakan pada aplikasi voice command terdapat proses perekaman perintah suara dan penerjemahan instruksi suara sehingga memerlukan waktu dalam pengolahan data perintah suara tersebut hingga dikirim ke Mikrokontroler robot dan juga dipengaruhi oleh noise atau suara lain yang tidak diinginkan. Berdasarkan hasil pengujian yang dilakukan untuk setiap pergerakan yang dapat dilakukan mobile robot antara lain pergerakan maju, mundur, putar kiri dan putar kanan, diperoleh nilai rata-rata persentase error sebagai berikut.

\section{SIMPULAN}

$$
\operatorname{error}(\%)=\frac{1,69 \%+1,76 \%+1,02 \%+1,73 \%}{4}=1,55 \%
$$

Berdasarkan hasil penelitian dapat diperoleh kesimpulan yaitu:

1. Aplikasi mobile robot yang dibuat pada Android dapat menerima data instruksi voice command yang diucapkan oleh user serta dapat mengontrol pergerakan pada mobile robot menggunakan komunikasi bluetooth dengan rentang jarak maksimal 12 meter.

2. Mobile robot dapat melakukan pergerakan maju, mundur, putar kiri serta putar kanan sesuai instruksi voice command menggunakan sensor rotary encoder dan Kompas GY-271 HMC5883L dengan error pergerakan rata-rata sebesar 1,55\% dan waktu respon 4-7 detik

\section{DAFTAR PUSTAKA}

[1] Jusuf Dwi Kariyanto, Ali Husein Alasiry, Fernando Ardila, dan Nofria Hanafi, "Navigasi Mobile Robot Berbasis Trajektori dan Odometry dengan Pemulihan Jalur Secara Otomatis", Teknik ElektronikaPoliteknik Elektronika Negeri Surabaya, 2014.

[2] Setiawan, Evan Taruna, "Pengendalian Lampu Rumah Berbasis Mikrontroler Arduino Menggunakan Smartphone Android", Teknik Informatika-STMIK Atma Luhur Pangkalpinang, 2014.

[3] Ardi, Jatra Kurnia, "Implementasi Sistem Voice Recognition Pada Robot Pemindah Objek Sebagai Sistem Navigasi", Teknik Elektro Fakultas Teknik-Universitas Brawijaya, 2014.

[4] Rahmad, Iwan Fitrianto dan Vidi Agung Fragastia, "Perancangan Navigasi Robot Berbasis Suara Menggunakan Android", Teknik Informatika Komputer-STMIK Potensi Utama, 2014. 
[5] Ermansyah, Septian Dwi. "Implementasi Sistem Voice Recognition dan Rotary Encoder pada Mobile Robot Sebagai Sistem Navigasi dan Perhitungan Posisis Robot", Teknik Elektro Fakultas Teknik-Universitas Jember, 2016. 